
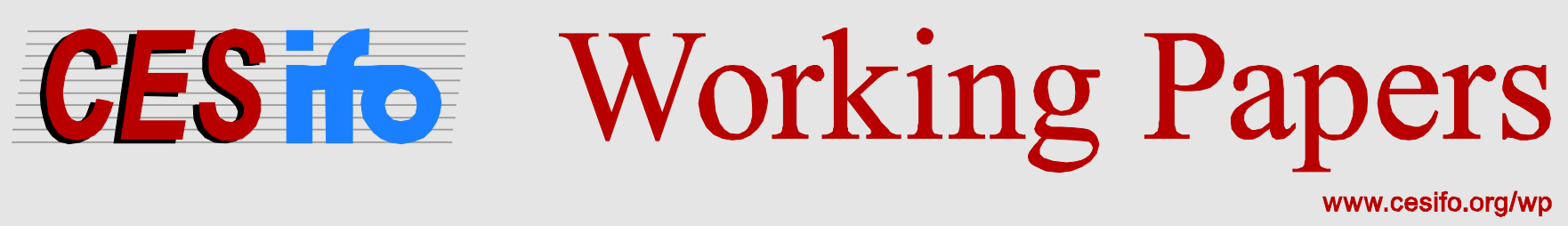

\title{
Policy Uncertainty and Manufacturing Investment: Evidence from U.S. State Elections
}

\author{
Cameron A. Shelton \\ Nathan Falk
}

\author{
CESIFO WORKING PAPER NO. 5846 \\ CATEgory 6: Fiscal POLICY, MaCROECONOMICS AND GROWTH \\ APRIL 2016
}

An electronic version of the paper may be downloaded

- from the SSRN website:

- from the RePEc website:

- from the CESifo website:

wWw.SSRN.com

Www.RePEc.org

www.CESifo-group.org/wp 


\title{
Policy Uncertainty and Manufacturing Investment: Evidence from U.S. State Elections
}

\begin{abstract}
We estimate the effect of electorally induced policy uncertainty on investment in the manufacturing sector. Because state governors exercise considerable influence over legislation and considerable discretion over regulation and permitting, and because the policies relevant to business investment vary systematically by party, uncertainty over the partisan affiliation of the future governor is a source of political risk to firms considering business investment. More importantly, the lack of an incumbent in a race due to term limits raises uncertainty over the outcome, providing a convincing instrument that allows us to estimate causal effects. We find that, in a state with average partisan polarization, in the calendar year of a gubernatorial election, the elasticity of investment to the eventual margin of victory is 0.027 . Both the significance and magnitude of this result are robust to various controls, measures, and estimators. Importantly, the investment decline is not reversed the following year. We show that own-state uncertainty is associated with a large and significant rise in neighboring states' investment, suggesting that rather than postponing investment to the future, the effect of policy uncertainty at the subnational level is to drive investment to alternative sites.
\end{abstract}

JEL-Codes: D720, E020, E640.

Keywords: policy uncertainty, investment, elections, US states.

Cameron A. Shelton

Claremont KcKenna College

USA - 91711 Claremont CA

cameron.shelton@cmc.edu
Nathan Falk

NERA Economic Consulting

USA - New York, NY 10036

jonathan.falk@nera.com

First draft: May 2014

This draft: March 2016 


\section{Introduction}

In the years since the Great Recession, US corporate profits have soared but business fixed investment remains depressed. ${ }^{1}$ Given the implications for both cyclic recovery and long-run growth, this divergence is a puzzle of some import. Several hypotheses have been put forth including capacity overhang, rising monopoly rents, and managerial incentives that deliver short-termism and riskaversion. ${ }^{2}$ Another influential line of reasoning focuses on the role of increased uncertainty. Greater uncertainty about energy prices, exchange rates, interest rates, environmental regulation, financial regulation, minimum wages, or any number of other political and economic variables increases uncertainty over the profitability of long-term investment projects raising the hurdle rate and reducing the number undertaken (Dixit 1992, among many others).

Some recent studies support this channel by demonstrating that at the firm-level, greater uncertainty over profits, as reflected in the exogenous component of stock-price volatility, is connected to lower rates of investment (Bloom, Bond, and van Reenen 2007; Stein and Stone 2011). Bloom (2009) shows that such firm-level uncertainty is correlated with geo-political events while Stein and Stone (2011) show that it is correlated with fluctuations in oil prices and exchange rates, each supporting the interpretation of the stock-price volatility as uncertainty relevant to the return on new projects.

Other studies argue that the effect is too small to be significant. Bachmann, Elstner, and Sims (2013) use survey data-cross-sectional disagreement in firm-level forecasts of business outlook, confirmed to be related to forecast error-to measure firm-level uncertainty which then becomes the shock in a two-variable SVAR of production and investment. They conclude that negative long-run shocks give rise to greater uncertainty but that uncertainty itself has little short-run "wait-and-see" effect on investment. Chugh (2009) likewise finds the effect to be small. Thus it remains in dispute whether firmlevel uncertainty has economically significant effects on investment.

It is a related question as to whether a rise in economic policy uncertainty is responsible for the observed decline in aggregate investment. Baker, Bloom, and Davis (2012) have derived a measure of macro-economic uncertainty but despite widespread use, the construction has been criticized as both manipulable and endogenous. ${ }^{3}$ We propose an alternate source of policy uncertainty derived from the differences between party platforms and the uncertainty over electoral outcomes.

Using an annual panel of data from US states spanning $1968-2004^{4}$, we relate state-specific manufacturing investment to the electoral and policy uncertainty stemming from close elections for governor. Election results, and thus pre- electoral uncertainty, are clearly dependent on pre-election economic circumstances. We address this by adding economic controls and by instrumenting for policy

\footnotetext{
${ }^{1}$ The Economist, 10/15/13, The profits prophet

${ }^{2}$ Robin Harding, 7/24/13, Corporate investment: a mysterious divergence

${ }^{3}$ Konczal, Mike "Whatever Happened to the Economic Policy Uncertainty Index?" August 6, 2013 guest post at The Big Picture and Konczal, Mike "What is the Economic Policy Uncertainty Index Really Telling Us?" August 8, 2012 post at Rortybomb

${ }^{4}$ The end date of the panel is limited by the availability of the longest single panel of state-level party polarization scores. We do check our results using a more recent polarization measure available for 1990-2012.
} 
uncertainty using gubernatorial term limits. The (exogenous) lack of an incumbent removes the electoral advantages of incumbency, increasing uncertainty over the outcome of the election and thence subsequent policy. We discuss the instrument in detail below, including documentation that the incumbent's predicted vote share is always above $50 \%$, no matter how bad the economy. ${ }^{5}$

By focusing on US states rather than countries, we first and foremost greatly facilitate the search for a valid instrument. So doing also limits the extent of unobserved institutional heterogeneity, improves the comparability of the data, and enables a larger sample than would be available in a cross-country setting. Finally, we have the ability to scale the electoral-uncertainty by the policy distance between the two alternatives (state parties are not clones of the national party) so as to achieve a measure of electorally induced policy-uncertainty. This would be more difficult in a cross-country setting. ${ }^{6}$

One potential drawback of using US states is that state policy may be less relevant for business investment decisions than federal policy. On the other hand, perhaps it is more relevant. US states do control a wide variety of relevant policies. State legislation bears on corporate profit taxes, environmental regulations, minimum wage laws, product and workplace safety regulations, labor union organization, the corporate share of benefits payments, job training and education of the local workforce, local infrastructure development, and more. Governors not only play a role in shaping legislation, they also exercise discretion in the implementation of regulations and negotiate special packages to attract certain star firms. Consider the following illustrative recent examples.

Governors have direct control over the identity and tenure of regulators, whose behavior can directly determine the pace of permitting and thence investment. In 2011, California Governor Jerry Brown pushed for state regulators to ease key requirements for oil and gas companies seeking permits to increase drilling. The top regulator, who had been hired by Brown's predecessor, Schwarzenegger, in response to allegations of corruption in the regulator's office, balked. A week later, Brown fired both this chief regulator and his top deputy, extracting an agreement from their replacements to streamline the permitting process.

Governors play a key role in wooing marquee investments from large firms which may in turn have spillover effects. In 2014, Volkswagen was considering whether to expand an existing plant in Chattanooga, Tennessee-which, it was suspected, would also lead to further investments by suppliers-or expand operations at a competing site in Mexico. At the same time, the United Autoworkers (UAW) sought to unionize the existing Chattanooga plant. While Volkswagen was careful to remain publically neutral on the issue of unionization, it was widely speculated that successful unionization in Chattanooga would lead Volkswagen to choose Mexico for expansion. Tennessee Governor Haslam not only organized a \$178 million package of grants from Tennessee to Volkswagen, ${ }^{7}$ he was an outspoken critic of the UAWs efforts, explicitly linking it to the prospects for this project and

\footnotetext{
${ }^{5}$ We thank an anonymous reviewer for pointing out that if the incumbent were sufficiently unpopular, the lack of an incumbent might make the election more competitive and less certain. Thus we show that in our sample, this is never the case.

${ }^{6}$ It is not impossible, see Canes-Wrone and Park (2012), but it does limit the available sample.

${ }^{7}$ Volkswagen picks Chattanooga for expansion despite labor strife, Nathan Bomey, Detroit Free Press, 7/14/14
} 
future investment by suppliers. ${ }^{8}$ Following the defeat of the unionization effort, Volkswagen announced they had chosen to expand in Tennessee, with planned investment totaling $\$ 900$ million over the next two years. ${ }^{9}$ When conceding defeat, UAW president Bob King fingered Governor Haslam foremost in his list of opponents. ${ }^{10}$

Finally, changes in the identity of the Governor can result in abrupt changes in policy, indicating that the identity of the governor matters. On July 1 2012, Democratic governor of North Carolina, Bev Purdue, vetoed a Republican-sponsored bill to allow fracking, citing concerns about environmental protection. The Republican-controlled legislature was narrowly unable to override her veto. But Governor Purdue did not seek reelection and was replaced by Republican Pat McCrory who signed a similar fracking bill into law on June $4,2014 .^{11}$

Business advocacy groups certainly write and behave as though state policies are important to their membership. Several organizations construct business climate indices ranking the relative hospitality of each state to the interests of a hypothetical representative firm. These state business climate indices play a large role in the perceptions of the business environment, appearing frequently in debates over state policy. ${ }^{12}$ To be sure, the organizations that create and promote these indices have political agendas and they construct and highlight selectively (Kolko, Neumark, and Mejia 2013). Nonetheless, in a study of how state policy environments predict state economic growth, Kolko, Neumark, and Mejia (2013) conclude that "business climate indices that emphasize taxes and costs predict economic growth, especially for the manufacturing sector" (p28).

Moreover, firms and industry groups contribute a great deal of money to gubernatorial candidates. And importantly, this money does not flow solely to the incumbent or the party expected to win, but tends to stay with a single party. For example, oil and gas sticks to the Republican party candidate even when that party doesn't offer the best chance of victory. Using data from FollowTheMoney.org on all contributions from the Oil \& Gas industry to gubernatorial candidates from 1990-2012, we ran a simple regression of the dollar total for that state-year-party on state $\mathrm{FE}$, year FE, party FE, and the identity of the winning party. The victorious party does receive more money $(\$ 72 k)$ but the effect is statistically insignificant. On the other hand, Republicans receive more than Democrats (\$121k), an amount which is significant at the $1 \%$ level. ${ }^{13}$ In other words, the oil and gas industry doesn't just care about access, it cares about having a Republican in office. In sum, state level policy is important for firm-level

\footnotetext{
${ }^{8}$ Gov. Haslam tries to keep UAW out of Tennessee, Joey Garrison, The Tennesseean, 2/6/14

${ }^{9}$ Volkswagen to Add S.U.V. Line to Chattanooga Plant, Aaron Kessler, NYTimes online, 7/14/14; Volkswagen picks Chattanooga for expansion despite labor strife, Nathan Bomey, Detroit Free Press online, 7/14/14

${ }^{10}$ King was quoted as saying "the unprecedented political interference by Governor Haslam, Senator Corker, and others was a distraction for Volkswagen employees and a detour from achieving Tennessee's economic priorities." (United Autoworkers union drops lost vote appeal at VW Tennessee Plant, Dominic Rushe, UK Guardian online 4/21/14)

${ }^{11}$ Reuters, Wade Rollins, 7/1/12, North Carolina governor rejects fracking law; Reuters, Marti Maguire, 6/4/14, North Carolina governor signs law paving way for fracking

${ }^{12}$ As one of a potentially long list of examples, see The Economist, 5/19/11, "Beware of the Yogurt"

${ }^{13}$ Results available upon request.
} 
investment decisions and the identity and partisan affiliation of the Governor are relevant to this policy. $^{14}$

In our baseline specification, we find that in a state with average partisan polarization, in the calendar year of a gubernatorial election, the elasticity of investment to the eventual margin of victory is -.027 . Thus if the margin of victory halves, raising uncertainty, investment will decline by $1.35 \%$. The effect is not reversed following the resolution of uncertainty. This lack of reversal is at odds with the traditional models of wait-and-see investment. But these models do not consider the possibility that the investment is flexible in location as well as time. We show that election-year investment in neighboring states rises when own-state uncertainty rises.

Interestingly, the result is heavily concentrated in states with professionalized legislatures. Woods and Baranowski (2006) note that professional legislators have more resources at their disposal but are also more career oriented in their choice of activities. Because oversight receives relatively little credit compared to legislative activity, professionalized legislatures tend to spend more time introducing and passing laws (Woods and Baranowski (2006)) and less time overseeing gubernatorial administration of laws, a conclusion that draws support from legislators themselves (Elling 1992, Baranowski 2001). As a result, the executive branch is, counter-intuitively, relatively less constrained as the legislature professionalizes. Professionalized legislatures have also been shown to enable rather than inhibit governors' implementation of their legislative agendas (Dilger, Krauss, Moffett 1995, Ferguson 2003). While this result is less well-understood, it may also rest on the idea that legislators in professional legislatures are more likely to be judged on quantity of legislative activity and thus more interested in participating in any agenda.

We are not the first to investigate the connection between electoral uncertainty and investment. Canes-Wrone and Park (2012) look at ten OECD countries and find that uncertainty over electoral outcomes is associated with a decline in private fixed investment. Julio and Yook (2013) find that irreversible FDI flows tend to fall prior to elections, especially in countries with a history of policy reversals. In the US, Canes-Wrone and Park (2013) find a decline in the quantity of home sales in advance of closely-contested gubernatorial elections.

While each of these is supportive of the connection between uncertainty and investment on a macroeconomic scale, none is a direct test of the idea that policy uncertainty retards business fixed investment in the United States - the current focus of public debate. The first and second studies group countries with a diverse set of political institutions and policy issues. While this is necessary to assemble a large set of elections, the resulting institutional heterogeneity is a concern. The last focuses on residential investment in the housing market rather than business investment. While residential investment is also part of GDP, it is arguably subject to a different calculus and is not relevant to

\footnotetext{
${ }^{14}$ Earlier versions of this paper simultaneously investigated uncertainty in control over the state legislature. We used both term limits on state legislators and redistricting, including measures of the magnitude of redistricting based on our own extension of Schaffner, Wagner, and Winburn (2004). Unfortunately, these instruments for legislative uncertainty were insufficiently strong to deliver informative results. Luckily, legislative uncertainty is largely orthogonal to gubernatorial uncertainty.
} 
productivity growth. Most importantly, we believe none of these studies convincingly addresses the potential simultaneity that arises because voters respond to the state of the economy.

The next section reviews the sources of our data, including the new data set on gubernatorial turnover that we have assembled for this study. Section 3 lays out our methods including the construction of electoral and policy uncertainty, the econometric specification, an extensive discussion of the instrument, and a discussion of the choice of estimator. Section 4 presents both the baseline results and a look at the effects of legislative professionalism. Section 5 concludes with a note on the broader applicability of our results.

\section{Data}

Our dataset is an annual panel of US states spanning from 1968 to 2004 . Our sample period begins in 1968 with the availability of data on legislative professionalism. Our main sample ends in 2004 with the end of the longest continuous panel of state party ideology scores from which we calculate distance between parties. However, we also conduct a robustness check using a more recent measure of state party ideology that runs from 1990-2012. In this section, we summarize the most important variables.

\section{Gubernatorial Vote Shares}

For elections from 1972-1996, we use data compiled by Claggett and David. These data needed to be adjusted for our analysis, however, because Claggett and David shifted vote totals for elections taking place in odd election years so that their totals would instead appear in the following even year alongside the majority of states. We have restored the proper election years. For elections in 1997 and 1998 we use vote counts from the Book of the States. Data for 1999-2012 come from the Statistical Abstract of the United States. In all cases, we record the percentage of the vote won by Democrats, Republicans, and Independents from which we typically calculate two-party vote-shares for Democrats and Republicans.

\section{Governor Turnover}

We assembled a comprehensive dataset indicating, for each gubernatorial election, whether the incumbent was running and, if not, why not. From this data we derive our instrument of exogenous variation in the degree to which an electoral result is uncertain ex-ante. Our coding distinguishes between the following alternatives: death/incapacity, term-limited, appointed to a higher office (e.g. US Ambassador), resigned to run for higher office (e.g. US Senate) whether successful or not, resigned for other political or personal reasons, recalled, impeached/convicted, or incumbent simply chose not to seek reelection. This last category is quite common and covers a wide range of circumstances. Upon extensive case research, this would seem to include governors who retire because a two-term limit is the norm but not the law, governors who retire due to age, and governors who retire to pursue attractive opportunities outside politics. But it also clearly includes governors whose decision is influenced by poor prospects for reelection. Rather than attempt to sift the tea leaves of the historical record to separate these various reasons and run the risk of mistaking rhetorical justification for true 
rationale, we avoid such cases altogether and focus on term-limits. The instrument is discussed in the next section.

It was frequently the case that the incumbent at the time of election was not the winner of the previous election but rather a lieutenant governor who had taken charge upon the resignation of the prior incumbent. In such cases, we had to decide whether this newcomer had, in fact, accrued the benefits of incumbency and should thus be counted as the incumbent, or whether we should rule this as a case of no incumbent running and code based on the previous election winner's reason for leaving office. For simplicity and transparency, we decided to rule based on the length of time the new incumbent had been in office prior to the election. Studies of the economic vote suggest that voters typically respond to performance only within the last year (Nannestad and Paldam 1994) so we placed our cutoff at one year. If the Governor had been in office at least twelve months prior to the election, he was considered the incumbent. If not, his predecessor was considered the incumbent and the predecessor's reasons for leaving office early would be relevant.

Consider the following example to illustrate. Suppose that a Governor is appointed to an Ambassadorial post in 2015 and resigns the Governorship mid-term, to be succeeded by her Lieutenant Governor who chooses to run in the next gubernatorial election in November 2016. If the Lieutenant Governor assumed office in October of 2015, 13 months prior to the election, then he would be considered the incumbent and this election would be coded "incumbent running for reelection". But if he didn't assume office until December 2015, only 11 months prior to the election, then he would not be considered the incumbent and this would be coded "incumbent resigned to assume appointed higher post."

\section{Polarization}

To measure the policy distance between the local Democrats and Republicans in a particular state, we use data from Berry et al. $(1998,2010)$ which gives a score to each party for each state and year. The scores are on a common single-dimensional left-right scale capturing their attitude toward government involvement in the economy. We are essentially assuming that all Democrats in a state-year, including both those who win office and those who challenge unsuccessfully, are characterized by this state- and year-specific party score and likewise for Republicans. The data cover $1960-2004$. As a robustness check, we also use Adam Bonica's DIME scores for the gubernatorial candidates. These are based on campaign contributions and cover 1990-2012, though coverage of most states doesn't begin until at least 1998 (Bonica 2013, 2014).

\section{Legislative Professionalism}

State legislatures vary a great deal in their remit. Some legislatures meet frequently, constituting fulltime jobs for their members who are well-paid and equipped with professional staffs (Squire 2007). Others are a part-time gig performed by members who concurrently hold other jobs. We use the Squire dataset of state legislative professionalism covering 1967-2010. It is comprised of three components: the level of salary and benefits awarded legislators, the time spent in session, and the staff and 
resources provided legislators. The Squire index normalizes each of these indices by the relevant score for the US Congress of the same year. There was a strong move to professionalism in a subset of states during the 1960s (King 2000) but during the bulk of our sample, scores are fairly stable over time, though they exhibit considerable variation in the cross-section. For more information, see Squire (2007).

\section{Real State Manufacturing Investment}

Our dependent variable is the log of real capital expenditure in manufacturing industries in a given state in a given year. We use data assembled by Chirinko and Wilson (2009) which cover the manufacturing sector (NAICS sectors 31-33) and span 1963-2006, with a break from 1979-1981. They are constructed from a representative sample of plants located in the state in question. Chirinko and Wilson construct and apply a deflator to achieve a series for real investment. ${ }^{15}$ We update them through 2012 using the original sources (the American Survey of Manufactures) and the authors' notes.

\section{Real State Manufacturing Output}

We control for the size of the state's manufacturing sector using a measure of value added in the manufacturing sector. The raw data, assembled by Chirinko and Wilson, derive from the ASM and are deflated using producer prices.

\section{Real State GDP}

We use state-level gross domestic product (GDP) data from the Bureau of Economic Analysis (BEA). We deflate using a state-specific cost of living index constructed by Berry, Fording, and Hanson (2000).

\section{Unemployment}

State-level unemployment data come from the Bureau of Labor Statistics and are available starting in 1976.

\section{Methods}

\subsection{Measuring Ex-Ante Uncertainty}

While the option value of waiting before investing depends on the perceived level of policy uncertainty in the period leading up to an election, we do not have good direct measures of this ex-ante uncertainty. The most direct method would be a real-time survey measure of firms' perceptions of state-level policy uncertainty. Several regional Fed branches conduct firm-level confidence surveys to construct diffusion indices. ${ }^{16}$ By taking the standard deviation of the qualitative responses, one can construct a measure of the cross-sectional dispersion of views which has been shown to predict future forecast errors and can thus be interpreted as a measure of uncertainty (Bachmann, Elstner, and Simms

\footnotetext{
${ }^{15}$ For a summary of their methods, see Chirinko and Wilson (2009).

${ }^{16}$ The Philadelphia Fed data series begins in 1968 while several others have started much more recently (New York 2001, Dallas 2004, Richmond 2008 though the latter do not release their underlying data).
} 
2013). However, the regional Fed surveys cover only their own district, hence only a few states, and with the notable exception of the Philadelphia Fed, the time series are also quite short, spanning only a few elections. The second-best alternative might be to use pre-election polls to measure how close the election is perceived to be. Unfortunately, regular pre-election polls are only rarely available for gubernatorial elections in our period and thus cannot be used in our main analysis.

Instead, we use the realized two-party vote-share of the gubernatorial candidates, assuming that elections which were close ex-post were perceived to be uncertain ex-ante. We take the difference between the winner and the second place finisher, termed vote margin, as a raw measure of the closeness of the election.

We have attempted to validate our ex-post measure using an ex-ante measure. By raiding the political news website Real Clear Politics, we have compiled pre-election polling for 96 gubernatorial elections between 2004 and 2012. The number of polls varies a great deal between elections, with some receiving a single poll and others as many as 60 . Figure 1 plots the relationship between our ex-post measure and the average polling margin. The regression has a coefficient of 1.1 and an R-squared of 0.85 , substantiating our choice of ex-post margin as an accurate proxy of ex-ante expected margin.

Because small shocks are more likely than large shocks, the effect of an increase in vote margin on electoral uncertainty should be declining in the vote margin. In other words, the effect on uncertainty is larger when moving from a $5 \%$ margin to a $10 \%$ margin than it is between $50 \%$ and $55 \%$. Because of this and to make our coefficients easily interpretable as elasticities, we construct our dependent variable based on the natural log of the vote margin. For state $s$ in year $t$, let vote margin be $V M_{s t}$. Our first key dependent variable is electoral uncertainty, $E U_{\text {st. }}$

$$
E U_{s t}=\left\{\begin{array}{cc}
\ln [101]-\ln \left[V M_{s t}+1\right] & \text { in an election year } \\
0 & \text { otherwise }
\end{array}\right.
$$

The second term is negative to ensure that a smaller vote margin produces greater uncertainty. The first term is present to normalize so that an unopposed election (VM $=100$ ) produces $E U=0$.

\subsection{Polarization}

Because there is a great deal of variation between states in the philosophy of government espoused by the average voter, both major parties adjust their platforms and legislative behaviors to accommodate local preferences. As a result, the policy-relevant difference between the two major parties varies a great deal from state to state. In states where there is very little difference between the parties, a given degree of electoral uncertainty might nonetheless translate into very little policy uncertainty. To control for this, we scale the measure of electoral uncertainty by a state-and-year-specific measure of 
the distance between the two parties. We then normalize this number by dividing by the sampleaverage value. Thus coefficient $\gamma$ in equation (3) represents the effect of election uncertainty in a state with average partisan polarization.

$$
P U_{s t}=E U_{s t} *\left[\frac{\text { polarization }_{s t}}{\frac{1}{S} \frac{1}{T} \sum_{T} \sum_{s} \text { polarization }_{s t}}\right]
$$

\subsection{Specification}

Equation (1) describes our main specification, where the panel indices $s$ and $t$ reference the US state and calendar year, respectively. Our vector of economic controls, $\mathbf{X}$, includes the logged-level and growth rates of real state GDP, the logged state unemployment rate, and the logged value added in the manufacturing sector. ${ }^{1718}$ We also include a single lag of the dependent variable, with the lag length chosen to minimize Schwarz' Bayesian information criterion. In some specifications, we include year fixed effects which may capture changes in interest rates, inflation, the federal tax treatment of investment, presidential election uncertainty, and other factors relevant to the investment decision.

$$
\log I_{s, t}=\rho \log I_{s, t-1}+\gamma P U_{s, t}+\vec{\beta}_{X} \vec{X}_{s, t}+\varepsilon_{s, t}+\mu_{s}
$$

The variable of interest is our measure of uncertainty surrounding the partisan affiliation of the victor, which was described in the previous sections. Our data are annual, and we relate the investment in a calendar year with the closeness of an election in that same calendar year. In years without elections, both electoral and policy uncertainty are zero. The vast majority of our elections take place in early November, suggesting that the concurrent calendar year is predominantly the proximate pre-election period and thus the proper window in which to observe effects on investment.

\subsection{The Instrument: Gubernatorial Term Limits}

Work on economic voting has made clear that voters respond to economic conditions and thus we face a potential simultaneity problem. An exogenous change in manufacturing investment in a state may

\footnotetext{
${ }^{17}$ Because it requires the development of separate instruments, and because these instruments are quite weak, we have looked into state legislative electoral uncertainty separately and do not include it in this paper. Interestingly, uncertainty over the partisan control of the state legislature is nearly orthogonal to gubernatorial electoral uncertainty, with correlations ranging from 0.05 to 0.1 depending on the threshold for uncertainty. Thus we feel comfortable omitting legislative uncertainty from our gubernatorial specifications.

${ }^{18}$ In response to requests, we have also included the growth rate of real state GDP and the one-year change in the state unemployment rate. Neither are significant so we have opted to report the baseline estimates only.
} 
well affect the broader economy and thence voter intentions, leading an election to be more or less closely fought, thereby affecting electoral uncertainty. Our basic controls for the state of the local economy (the level in both unemployment and income) should account for many scenarios, but a variety of potential shocks remain. Thus we develop an exogenous instrument for electoral uncertainty.

Our instrument for electoral uncertainty in gubernatorial elections is the presence of a term-limited incumbent. Incumbents enjoy a large electoral advantage (name recognition, free press, etc.) and are reelected at a high rate (Carey, Niemi, Powell 2000 among many others), thus an election in which there is no incumbent running is generally an election whose outcome is less certain. However, it is possible that an incumbent's party is saddled with a bad economy or a tarnished party brand. If the party is actually an underdog, then removal of this incumbent and his/her incumbency advantages might, by further handicapping the underdog, make the election outcome more easily forecast. To rule out such a scenario, we have regressed the incumbent party's realized two-party vote share on state real GDP growth, the number of years the party has held the governorship, and the change in the incumbent party's share of state legislative seats in the same election. Length of time in office has been shown to affect a party's vote share (Nannestad and Paldam 1994), and the change in legislative seat share is intended to capture the concurrent strength of the party brand apart from gubernatorial candidates. We then note that none of the predicted values falls below $50 \%$. In other words, the incumbent party is never the underdog based solely on party label and economic conditions. Hence the removal of the incumbent is likely to make the election more closely contested. ${ }^{19}$

We have collected data on the actions of the incumbent governor during all gubernatorial elections during our sample period (see figure 2). Naturally, many incumbents voluntarily choose not to run. In many cases, the decision not to run could be the result of poor prospects of reelection springing from policy choices in office or the state of the local economy. At a casual reading of electoral histories, many of the reasons cited-poor health, advanced age, or attractive private sector opportunitiesseem plausibly exogenous. However, surface-level justifications may hide a deeper truth and we do not wish to wade into these waters. On the flip side, there are many instances where an incumbent resigned the governorship to pursue higher office (e.g. US Senator or US President). These are likely cases where the incumbent's political fortunes are riding high. To the extent that their political fortune is due to the state of the local economy, or policy choices while in office, one may worry that such incumbent exits are not exogenous to the system we are estimating. Thus we focus solely on those reasons that seem plausibly exogenous: death or incapacity while in office, appointment to higher office (e.g. US Ambassador or member of the President's cabinet), or ineligibility to run due to termlimits. Of these three, the last makes up the vast majority of our cases (see figure 3).

As of this writing, governors of 36 states are subject to term limits. One third of these states impose a lifetime limit of two terms. Two thirds of these states limit the governor to two successive terms with no lifetime limit. These numbers have changed over our sample period as there has been a slow trend

\footnotetext{
${ }^{19}$ Our regression does not rule out the incumbent party being the underdog based on the characteristics of the incumbent governor him/herself. But in such a case, the removal of the incumbent is likely to improve the prospects of the incumbent party, once again leading to a closer election.
} 
toward adoption of term limits. Currently, most governors serve four-year terms of office, with Vermont and New Hampshire constituting exceptions. However, this too has changed during our sample period; two-year terms were more common at the beginning of the sample. As a result of the variety in term lengths, term limits, the election year cycle, and the electoral fortune of incumbents, the incidence of term-limited incumbents is extremely diffuse (see figure 3 ). In other words, it is not the case that term-limited governors appear in a fixed collection of states with a regular periodicity.

Gubernatorial term limits are an extremely strong instrument. In our baseline specifications, first stage F-statistics on the excluded instrument are in excess of 100. Even when the sample is split by legislative professionalism, the first-stage $\mathrm{F}$ statistics range between 40 and 210 .

For the incumbent governor to be term limited and ineligible to run in year $t$, she must have won reelection in the previous election of year $t-4$. The exclusion restriction would not be met if incumbent electoral success in year $t-4$ is related to manufacturing investment in year $t$. One possibility for this is that high investment in year $t-4$ leads to both successful reelection of the incumbent in $t-4$ (and thus her ineligibility due to term limits in year $t$ ) as well as lower investment in year $t$ (perhaps due to lingering overcapacity). A variation on this channel would be if the governor took actions to stimulate investment in year $t-4$ which then prevent similar actions in year $t$ (perhaps due to an inter-temporal budget constraint).

Given the four year time-span involved, we don't believe these are convincing stories. Nonetheless, to strengthen our argument that the instrument satisfied the exclusion restriction, we have run specification (1) including the instrument as a standard explanatory variable on the right-hand side. As expected, the instrument (term limits) is not statistically significant while the uncertainty measure remains significant, suggesting that the confounding channels hypothesized above are, if they do exist, not strong.

\subsection{Estimators}

Because current investment likely depends on past investment, we are in the position of estimating a dynamic panel. Because of the dimensions of our panel $(T=34, N=50)$, the choice of proper estimator is not clear-cut.

In a dynamic panel, the least-squares dummy variable (LSDV) estimator is biased for small T, regardless of the cross-sectional size of the panel, N (Nickel 1981). This is essentially because any innovation in period $t-1$ will contribute to both the lagged dependent variable and to the fixed effect, thus ensuring that they are correlated. However, $\varepsilon_{\mathrm{i}, \mathrm{t}-1}$ is only one of $\mathrm{T}$ terms in the fixed effect, thus as $\mathrm{T} \rightarrow \infty$, the correlation and thus the bias decline to zero. The natural question then, is "how big must $\mathrm{T}$ be before the bias can be ignored?" Judson and Owen (1999) find that for $\mathrm{T}=30$, the bias for $\beta$ when estimated using the LSDV estimator is between 1 and $3 \% .{ }^{20}$ While this seems small, we try to employ system GMM (Blundell and Bond 1998) as well.

\footnotetext{
${ }^{20}$ The bias depends on the magnitude of the true parameter estimate. See Judson and Owen (1999) Table 1.
} 
However, difference and system GMM estimators are designed to address dynamic panel bias in short panels. They result in a number of instruments which grows quadratically with $\mathrm{T}$. As a result, "instruments can over-fit instrumented variables, failing to expunge their endogenous components and biasing coefficient estimates towards those from non-instrumenting estimators." (Roodman 2009b, p139) Over-fitting occurs when the number of instruments, $j$, is large compared to the number of panels, N. But Roodman (2009b) argues that there is relatively little practical guidance on the size of the bias for a given sample size and number of instruments. While the magnitude of the bias is not yet clear, there is a strong sense that one can mitigate it by reducing the number of instruments. The current solution is to use a subset of the available lags to produce a smaller set of instruments. Roodman (2009b) describes procedures for collapsing instruments and further work on finding the best combination continues. Roodman (2009b) shows that collapsed instruments cause less bias and increase the ability of the Hansen test to detect violations, albeit at the cost of increased variance. ${ }^{21}$

We estimate equation (1) using both 2SLS panel fixed effects and two-step system GMM with collapsed instruments so that there is just one instrument for each variable and lag length, rather than one for each time period, variable, and lag length. ${ }^{22}$ In each case we use the strictly exogenous instrument for political uncertainty described in the previous subsection.

After collapsing, we are left with $j=47$ instruments and $N=50$ panels (states). Hansen's test of overidentifying restrictions cannot reject the null of valid instruments. In later specifications, we split the sample in two according to whether a state's legislature is relatively more or less professional. This results in $j=47, N=25$. At this point, the $\mathrm{p}$-value for Hansen's test soars and it seems likely that Hansen's test has lost power (Roodman 2009b) which may concurrently suggest bias from over-fitting. Unfortunately, this means we are unable to use system GMM on that part of the sample in which the effect is concentrated (the states with professionalized legislatures). As a result, we rely on FE IV for the bulk of the paper. A few results from system GMM are shown in table 4 to confirm that system GMM delivers similar results but is unreliable in our long panel.

\section{Results}

\subsection{Baseline Specification}

Table 1 shows the results of our baseline regression of manufacturing investment on the extent of election-induced policy uncertainty that year plus economic controls and state fixed effects. Because both independent and dependent variables are in logs, the coefficient of interest (top row) is interpretable as an elasticity. As expected, doubling our measure of policy uncertainty leads to a $2.7 \%$ decline in investment. Adding a time trend (column 2) allays fears that the result is driven by a secular

\footnotetext{
${ }^{21}$ Roodman (2009b) Table 1 gives Monte Carlo estimates of bias only for the parameter, $\rho$. Estimates of bias for the parameters of interest, $\beta$, are not reported.

${ }^{22}$ We use the two-step estimator with robust standard errors (Roodman's xtabond2 in Stata).
} 
trend in US manufacturing. Adding year FE (column 3) shows the result is robust to a variety of national macroeconomic and macro-political indicators. Adding unemployment (column 4) limits the sample but reconfirms the result. Using an alternate measure of political polarization, indeed one that is more closely tied to the candidates in question, actually strengthens the result (column 5). ${ }^{23}$

\subsection{Legislative Professionalism}

We have argued that the stakes are likely to be greater where the legislature is professionalized and thus both governor and legislature are more capable of intervention. Table 2 shows the effects of splitting the sample at the median value of legislative professionalism. It is clear that it is in states with high legislative professionalism that we see the greater effect of uncertainty in gubernatorial elections. Indeed, when year FE are included (columns 3 and 4), the estimated elasticity in the more professional half of the sample is in excess of 0.07 . The results are also robust to using Bonica's DIME measure of polarization (available on request).

As we argued in section 3.5, we believe that in a panel of these dimensions, the FE estimator is more reliable than GMM. Nonetheless, we have reported GMM estimates of the baseline specification and the split by legislative professionalism in table 3. Comparing the GMM estimates (table 3, columns 2 and 3 ) to the comparable FE estimates (table 2, columns 5 and 6 ) shows that both estimators find the effect to be concentrated in the more professional legislatures. Moreover, the estimated magnitudes are comparable. So the GMM results provide a useful check that an erroneous estimator is not driving either the flavor or strength of our results.

\subsection{Stolen by the Neighbors}

The wait-and-see theory of investment under uncertainty suggests that we should see a rebound of investment once the election has concluded and the uncertainty is resolved. The first five columns of table 4 show that the effect is isolated to the election year. Manufacturing investment in the two years before the election is unrelated to electoral uncertainty, which reassures us of the specification. Puzzlingly, we see no post-electoral rebound of investment.

One potential explanation is that the investment does not return because it has already been enacted somewhere else. The relevant competing sites no doubt vary according to the geography of a particular industry. The primary competitors for automotive plants may be the right-to-work states while competitors for military naval vessels would necessarily be coastal states. Competitive states may also vary over time; silicon wafer production used to be the exclusive preserve of California and Texas but

\footnotetext{
${ }^{23}$ A keen-eyed reader may notice that the Fording measure of uncertainty admits only 49 states whereas Bonica's DIME measure admits all 50. Nebraska's legislature is officially non-partisan though the individuals who comprise it do have known party affiliations. Thus Fording's chamber-based measure of partisan difference is not defined whereas Bonica's legislator-based measure is.
} 
has spread across the globe. Unable to track all the relevant geographic, socio-economic, and regulatory factors for the various components of our aggregate measure of investment, we simply look at neighboring states.

For each state-year, we take the sum of the residuals from our preferred regression (table 1, column 2) for all the neighboring states. This is our new dependent variable. We then regress it on our uncertainty measure and bootstrap to achieve the proper standard errors. In this way, we are estimating whether electoral uncertainty in one state leads to an unusual rise in concurrent investment in neighboring states, after controlling for the economic and political situation in these states. We find that it does (table 4 , column 6 ). The estimated elasticity is 0.046 with a p-value of less than $1 \%$.

\section{Discussion}

We have estimated the effect of electorally induced policy uncertainty on investment in the manufacturing sector. We have chosen US states because they afford a large sample with high quality comparable data and relatively homogeneous political institutions. More importantly, term limits provide a convincing instrument allowing us to estimate causal effects. Because state governors exercise considerable power over legislation and considerable discretion over regulation and permitting, and because the policies relevant to business investment vary systematically by party, uncertainty over the partisan affiliation of the future governor is a source of political risk to firms considering investing in-state. Thus we have used electoral uncertainty, scaled by the policy distance between parties, as a measure of policy uncertainty. Surprisingly, we find that in the calendar year of a gubernatorial election, state investment in the manufacturing sector is greater when the election is less certain. The elasticity is -0.027 , implying that doubling the electoral uncertainty will result in a $2.7 \%$ fall in investment. This is in line with the sole comparable prior study. Canes-Wrone and Park (2012) find that in OECD countries, elections with above average partisan polarization and a vote margin within 15 points witness a 2 percentage point decline in private fixed investment in the quarter prior to the election.

However, the post-electoral dynamics of investment that we find are significantly different than those of Canes-Wrone and Park. In their case, there is some evidence of a post-electoral boom, consistent with wait-and-see investment returning upon resolution of the electoral uncertainty. We find no such reversal the following year. Instead, investment in neighboring states rises significantly during the year of electoral uncertainty. So at least in manufacturing, state-level policy uncertainty leads to redirection rather than postponement of investment. The likely cause is that relocating across national borders is more onerous than relocating across state borders. As a result, on the margin, uncertainty in national policy results in postponement whereas uncertainty in state policy results in relocation. 


\section{References}

Bachmann, Rüdiger, Steffen Elstner, and Eric R. Sims. 2013. "Uncertainty and Economic Activity: Evidence from Business Survey Data." American Economic Journal: Macroeconomics, 5(2): 217-49.

Baker. S., Bloom, N. and Davis, S. (2012), "Measuring economics policy uncertainty", Stanford mimeo.

Baranowski, Michael. 2001. "Legislative Professionalism and Influence on State Agencies." Politics \& Policy 29: 147-61.

Basehart, Harry and John Comer. 1991. "Partisan and Incumbent Effects in State Legislative Redistricting." Legislative Studies Quarterly, 16(1): 65-79.

Beyle, Thad, Richard G. Niemi, and Lee Sigelman. 2002. "Gubernatorial, Senatorial, and State-Level Presidential Job Approval Ratings: The U.S. Officials Job Approval Ratings (JAR) Collection." State Politics and Policy Quarterly, 2(Fall): 215-229.

Berry, William D., Evan J. Ringquist, Richard C. Fording, Russell L. Hanson and Carl E. Klarner. 2010. "Measuring Citizen and Government Ideology in the U.S. States: A Reappraisal." State Politics and Policy Quarterly, 10: 117-135.

Berry, William D., Evan J. Ringquist, Richard C. Fording, Russell L. Hanson. 1998. "Measuring Citizen and Government Ideology in the American States, 1960-93. American Journal of Political Science, 42(1): 327-348.

Berry, William D., Richard C. Fording, Russell L. Hanson. 2000. An Annual Cost of Living Index for the American States, 1960-1995. The Journal of Politics, Vol. 62, No. 2 (May), pp. 550-567

Bloom, Nicholas. 2009. "The Impact of Uncertainty Shocks." Econometrica, 77(3): pp 623-85.

Bloom, Nick, Steven Bond, and John van Reenen. 2007. "Uncertainty and Investment Dynamics." Review of Economic Studies, 74(2): 391-415

Bloom, Nicholas, Max Floetotto, Nir Jaimovich, Itay Saporta-Eksten, Stephen Terry. 2012. "Really Uncertain Business Cycles." NBER working paper 18245.

Blundell, Richard and Stephen Bond. 1998. "Initial conditions and moment restrictions in dynamic panel data models." Journal of Econometrics 87: 115-143.

Bonica, Adam. 2013. Database on Ideology, Money in Politics, and Elections: Public version 1.0 [Computer file]. Stanford, CA: Stanford University Libraries.

Bonica, Adam. 2014. "Mapping the Ideological Marketplace". American Journal of Political Science, 58 (2): 367-387.

Canes-Wrone, Brandice and Jee-Kwang Park. 2012. "Electoral Business Cycles in OECD Countries." American Political Science Review, 106(1): 103-122. 
Canes-Wrone, Brandice and Jee-Kwang Park. 2013. "Elections, Uncertainty, and Irreversible Investment" British Journal of Political Science, August: 1-24.

Carey, John M., Richard G. Niemi, and Lynda W. Powell. 2000. "Incumbency and the Probability of Reelection in State Legislative Elections." The Journal of Politics, 62(3): 671-700.

Carson, Jamie L. and Michael H. Crespin. 2004. "The Effect of State Redistricting Methods on Electoral Competition in United States House of Representatives Races."

Carson, Jamie L., Michael H. Crespin, Charles J. Finocchiaro, and David W. Rohde. 2007. "Redistricting and Party Polarization in the U.S. House of Representatives." American Politics Research, 35(6):878-904.

Chirinko, Robert S. and Daniel J. Wilson. 2009. "A State Level Database for the manufacturing Sector: Construction and Sources. FRB San Francisco Working Paper 2009-21.

Chugh, Sanjay. (2009) "Firm Risk and Leverage-Based Business Cycles." unpublished manuscript.

Dilger, Robert J., George A. Krauss, and Randolph R. Moffett. 1995. "State Legislative Professionalism and Gubernatorial Effectiveness." Legis/ative Studies Quarterly, 20(4): 553-571.

Dixit, Avinash. 1992. "Investment and Hysteresis." The Journal of Economic Perspectives, 6(1): 107-132.

Elling, Richard C. 1992. Public Management in the States: A Comparative Study of Administrative Performance and Politics. Westport, CT: Praeger.

Ferguson, Margaret R. 2003. "Chief Executive Success in the Legislative Arena." State Politics and Policy Quarterly. 3(2): 158-182.

Julio, Brandon and Youngsuk Yook. 2013. "Policy Uncertainty, Irreversibility, and Cross-Border Flows of Capital." Unpublished manuscript.

Julio, Brandon and Youngsuk Yook. 2012. "Political Uncertainty and Corporate Investment Cycles." Journal of Finance, 67(1): 45-83.

Judson, Ruth A. and Ann L. Owen. 1999. "Estimating dynamic panel data models: a guide for macroeconomists." Economics Letters, 65: 9-15.

King, James D. 2000. "Changes in Professionalism in U.S. State Legislatures." Legislative Studies Quarterly, 25(2): 327-343.

Kolko, Jed, David Neumark and Marisol Cuellar Mejia. 2013., "What do Business Climate Indexes Teach Us About State Policy and Economic Growth?" Journal of Regional Science, 53: 220-255.

Hardy, Leroy, Alan Heslop, and Stuart Anderson (eds). 1981. "Reapportionment Politics: The History of redistricting in the 50 States." Sage Publications. Beverly Hills.

Holtz-Eaken, Douglas, Whitney Newey, and Harvey S. Rosen. 1988. "Estimating Vector Autoregressions with Panel Data. Econometrica, 56(6):1371-1395. 
Malhotra, Neil. 2006. "Government Growth and Professionalism in U.S. State Legislatures." Legislative Studies Quarterly, 31(4): 563-584.

Malhotra, Neil. 2008. "Disentangling the Relationship between Legislative Professionalism and Government Spending." Legislative Studies Quarterly, 33(3): 387-414.

Nannestad, Peter and Martin Paldam. 1994. "The VP-function: A survey of the literature on vote and popularity functions after 25 years." Public Choice 79: 213-245.

Nickel, Stephen. 1981. "Biases in Dynamic Models with Fixed Effects." Econometrica, 49(6): 1417-1426.

Roodman, David. 2009a. "How to do xtabond2: An introduction to difference and system GMM in Stata." The Stata Journal, 9(1): 86-136.

Roodman, David. 2009b. "A Note on the Theme of Too Many Instruments." Oxford Bulletin of Economics and Statistics, 71(1): 135-158.

Scaffner, Brian, Micahel Wagner, and Jonathan Winburn. 2004. "Incumbents out, Party in? Term Limits and Partisan Redistricting in State Legislatures" State Politics \& Policy Quarterly, 4(4): 396-414.

Shor, Boris and Nolan McCarty. 2011. "The Ideological Mapping of American Legislatures." American Political Science Review, 105(3): 530-551.

Squire, Peverill. 2007. "Measuring State Legislative Professionalism: The Squire Index Revisited." State Politics \& Policy Quarterly, 7(2): 211-227.

Stein, Luke and Elizabeth Stone. 2011. "The Effect of Uncertainty on Investment, Hiring, and R\&D: Causal Evidence from Equity Options", Stanford mimeo

Woods, Neal and Baranowski, Micahel. 2006. "Legislative Professionalism and Influence on State Agencies: The Effects of Resources and Careerism." Legislative Studies Quarterly, 31: 585-609. 
Table 1: Gubernatorial Electoral Uncertainty Depresses Manufacturing

Investment

\begin{tabular}{|c|c|c|c|c|c|}
\hline \multirow{5}{*}{$\begin{array}{l}\text { estimator } \\
\text { instrument for close elections } \\
\text { dependent variable } \\
\text { sample }\end{array}$} & (1) & $(2)$ & (3) & $(4)$ & (5) \\
\hline & \multicolumn{5}{|c|}{ fixed effects IV with robust standard errors } \\
\hline & \multirow{2}{*}{\multicolumn{5}{|c|}{$\begin{array}{c}\text { no incumbent governor due to death, term-limits, or appointment } \\
\text { Log of State Manufacturing Investment }\end{array}$}} \\
\hline & & & & & \\
\hline & & 1968-2004 & & $1976-2004$ & 1990-2012 \\
\hline \multirow[t]{2}{*}{ Uncertainty measure (Fording) } & $-0.0268 * *$ & $-0.0259 * *$ & $-0.0310 * *$ & $-0.0271 * *$ & \\
\hline & $(0.0113)$ & $(0.0113)$ & $(0.0144)$ & $(0.0108)$ & \\
\hline \multirow[t]{2}{*}{ Uncertainty measure (DIME) } & & & & & $-0.0465 * *$ \\
\hline & & & & & $(0.0190)$ \\
\hline \multirow[t]{2}{*}{ Lag of Log of State Mfg Investment } & $0.586 * * *$ & $0.574 * * *$ & $0.562 * * *$ & $0.459 * * *$ & $0.366 * * *$ \\
\hline & $(0.0193)$ & $(0.0195)$ & $(0.0197)$ & $(0.0231)$ & $(0.0433)$ \\
\hline \multirow[t]{2}{*}{ Log of State Mfg GDP } & $0.173^{* * *}$ & $0.159 * * *$ & $0.130 * * *$ & $0.405^{* * *}$ & $0.207 * * *$ \\
\hline & $(0.0183)$ & $(0.0187)$ & $(0.0175)$ & $(0.0382)$ & $(0.0797)$ \\
\hline \multirow[t]{2}{*}{ Log of Real State GDP } & $0.276 * * *$ & $0.178 * * *$ & $0.182 * * *$ & -0.0164 & $0.734 * * *$ \\
\hline & $(0.0363)$ & $(0.0458)$ & $(0.0426)$ & $(0.0627)$ & $(0.217)$ \\
\hline \multirow[t]{2}{*}{ State real GDP growth rate } & $0.637 * * *$ & $0.680 * * *$ & $0.952 * * *$ & 0.123 & -0.465 \\
\hline & $(0.143)$ & $(0.143)$ & $(0.153)$ & $(0.186)$ & $(0.392)$ \\
\hline \multirow[t]{2}{*}{ Time Trend } & & $0.00410 * * *$ & & -0.00177 & $-0.0189 * * *$ \\
\hline & & $(0.00118)$ & & $(0.00172)$ & $(0.00497)$ \\
\hline \multirow[t]{2}{*}{ Log of State Unemployment Rate } & & & & $-0.218 * * *$ & $-0.437 * * *$ \\
\hline & & & & $(0.0275)$ & $(0.0610)$ \\
\hline year FE & no & no & yes & no & no \\
\hline Observations & 1,662 & 1,662 & 1,662 & 1,270 & 524 \\
\hline R-squared & 0.815 & 0.817 & 0.848 & 0.737 & 0.425 \\
\hline Number of states & 49 & 49 & 49 & 49 & 50 \\
\hline First Stage F Statistic & 307 & 306.5 & 214 & 301.6 & 112.6 \\
\hline
\end{tabular}

Standard errors in parentheses

$* * * p<0.01, * * p<0.05, * p<0.1$ 
Table 2: The Effect is Concentrated in States with Professionalized Legislatures

\begin{tabular}{|c|c|c|c|c|c|c|}
\hline \multirow{6}{*}{$\begin{array}{l}\text { estimator } \\
\text { instrument for close elections } \\
\text { dependent variable } \\
\text { professionalism of the state legislature } \\
\text { sample }\end{array}$} & (1) & $(2)$ & (3) & (4) & (5) & (6) \\
\hline & \multicolumn{6}{|c|}{ fixed effects IV with robust standard errors } \\
\hline & \multirow{2}{*}{\multicolumn{6}{|c|}{ no incumbent governor due to death, term-limits, or appointment }} \\
\hline & \multicolumn{5}{|c|}{ Log of State Manufacturing Investment } & \\
\hline & high & low & high & low & high & low \\
\hline & \multicolumn{4}{|c|}{$1968-2004$} & \multicolumn{2}{|c|}{ 1976-2004 } \\
\hline \multirow[t]{2}{*}{ Uncertainty measure (Fording) } & $-0.0394 * * *$ & -0.0119 & $-0.0714 * * *$ & -0.0118 & $-0.0500 * * *$ & -0.0103 \\
\hline & $(0.0137)$ & $(0.0171)$ & $(0.0273)$ & $(0.0183)$ & $(0.0133)$ & $(0.0171)$ \\
\hline \multirow[t]{2}{*}{ Lag of Log of State Mfg Investment } & $0.660 * * *$ & $0.446 * * *$ & $0.648 * * *$ & $0.445^{* * *}$ & $0.575 * * *$ & $0.393 * * *$ \\
\hline & $(0.0279)$ & $(0.0294)$ & $(0.0266)$ & $(0.0307)$ & $(0.0332)$ & $(0.0341)$ \\
\hline \multirow[t]{2}{*}{ Log of State Mfg GDP } & $0.0727^{* * *}$ & $0.477^{* * *}$ & $0.0491 * * *$ & $0.415^{* * *}$ & $0.286 * * *$ & $0.477^{* * *}$ \\
\hline & $(0.0178)$ & $(0.0473)$ & $(0.0161)$ & $(0.0467)$ & $(0.0597)$ & $(0.0562)$ \\
\hline \multirow[t]{2}{*}{ Log of Real State GDP } & $0.158 * * *$ & 0.0446 & $0.175^{* * *}$ & 0.0640 & 0.0441 & -0.0344 \\
\hline & $(0.0539)$ & $(0.0761)$ & $(0.0478)$ & $(0.0718)$ & $(0.0850)$ & $(0.0936)$ \\
\hline \multirow[t]{2}{*}{ State real GDP growth rate } & $0.766 * * *$ & 0.169 & $1.179 * * *$ & 0.224 & 0.353 & -0.256 \\
\hline & $(0.180)$ & $(0.224)$ & $(0.176)$ & $(0.260)$ & $(0.228)$ & (0.299) \\
\hline \multirow[t]{2}{*}{ Time Trend } & $0.00354 * *$ & -0.000508 & & & -0.00226 & -0.00249 \\
\hline & $(0.00138)$ & $(0.00202)$ & & & $(0.00214)$ & $(0.00279)$ \\
\hline \multirow[t]{2}{*}{ Log of State Unemployment Rate } & & & & & $-0.202 * * *$ & $-0.220 * * *$ \\
\hline & & & & & $(0.0330)$ & $(0.0449)$ \\
\hline year FE & no & no & yes & yes & no & no \\
\hline Observations & 848 & 814 & 848 & 814 & 648 & 622 \\
\hline R-squared & 0.821 & 0.828 & 0.867 & 0.851 & 0.753 & 0.727 \\
\hline Number of states & 25 & 24 & 25 & 24 & 25 & 24 \\
\hline First Stage F Statistic & 121.9 & 210.8 & 39.73 & 193 & 121.7 & 202.4 \\
\hline
\end{tabular}

Standard errors in parentheses

$* * * p<0.01, * * p<0.05, * p<0.1$ 
Table 3: GMM Tells the Same Story But Suffers From Too Many Instruments

$$
\text { (1) }
$$

(2)

two-step system GMM with collapsed instruments and robust std errors

estimator

instrument for close elections

dependent variable

professionalism of the state legislature

no incumbent governor due to death, term-limits, or appointment

sample Log of State Manufacturing Investment

all states more professional less professional

Uncertainty measure (Fording)

Lag of Log of State Mfg Investment

$-0.010$

- 2004

(0.0151)

$0.429 * * *$

(0.0602)

$0.487 * * *$

(0.0601)

0.0861 *

(0.0471)

$-0.410$

(0.438)

$-0.00837 * * *$

(0.00179)

$-0.322 * * *$

(0.0782)

(0.0107)

$0.582 * * *$

(0.0829)

$0.360 * * *$

(0.0990)

0.0911

(0.0670)

0.338

(0.642)

$-0.00841^{* *}$

(0.00429)

$-0.273 * * *$

(0.100)

(0.0161)

$0.352 * * *$

(0.0618)

$0.586 * * *$

$(0.0930)$

0.0368

(0.132)

$-0.745$

(0.651)

$-0.00932 *$

(0.00559)

$-0.341 * *$

(0.163)

Observations

Number of states

1,270

648

622

Number of instruments

49

47

0.360

0.000

25

47

0.975

0.006

0.261

24

Test for AR(1) in first differences: $p$-value

0.623

Standard errors in parentheses

$* * * \mathrm{p}<0.01, * * \mathrm{p}<0.05, * \mathrm{p}<0.1$ 
Table 4: Diverted From the Neighbors

(1)

(2)

(3)

(4)

(5)

(6)

fixed effects IV with robust standard errors

IV with bootstrapped std errors

estimator
instrument for close elections

no incumbent governor due to death, term-limits, or appointment

Sum of Residuals for Neighboring

States from Table 1, Column 2

dependent variable

Log of State Manufacturing Investment

$\begin{array}{lc} & 0.0151 \\ \text { Uncertainty measure (Fording) } t+2 & (0.0107)\end{array}$

Uncertainty measure (Fording) $t+1$

0.00235

(0.0106)

Uncertainty measure (Fording) t

Uncertainty measure (Fording) t-1

(0.0113)

$0.0462 * * *$

-0.0123
$(0.0110)$

$(0.0124)$

Uncertainty measure (Fording) t-2

Lag of Log of State Mfg Investment

$0.571 * * *$

$0.570 * * *$

$0.560 * * *$

(0.0197)

(0.0195)

(0.0195)

(0.0115)

Log of State Mfg GDP

Log of Real State GDP

(0.0183)

$0.183^{* * *}$

(0.0184)

$0.159 * * *$

$0.161 * * *$

$0.162 * * *$

$0.174 * * *$

(0.0187)

(0.0186)

(0.0186)

(0.0463)

(0.0459)

$0.179 * * *$

$181 * * *$

$0.00605^{* * *}$

$0.00496 * * *$

$0.0458)$

(0.0456)

(0.0459)

State real GDP growth rate

(0.00121)

(0.00119)

(0.00118)

$0.00433 * * *$

$0.00415^{* * *}$

$0.760 * * *$

$0.792 * * *$

$0.680 * * *$

(0.00118)

(0.00117)

Time Trend

(0.139)

(0.143)

(0.137)

$0.785^{* * *}$

1,564

1,613

1,662

1,662

(0.141)

Observations

0.829

0.824

0.817

0.819

1,663

1,809

Number of states

49

49

49

0.819

0.010

First Stage F Statistic

360.4

306.5

341.4

297.2 
Figure 1: Ex-Post and Ex-Ante measures of Electoral Uncertainty

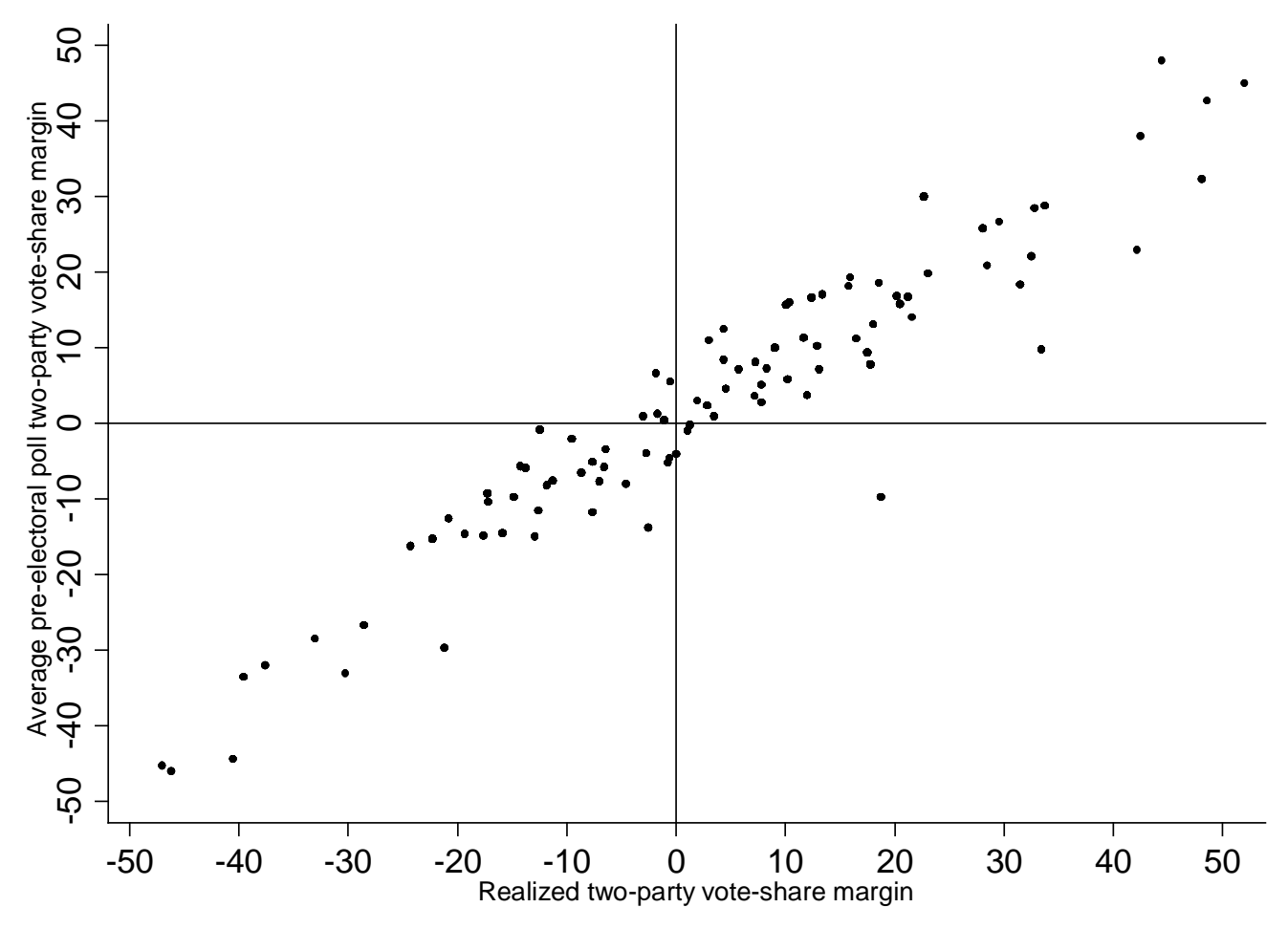


Figure 2: Sources of Gubernatorial Turnover: The Full Spectrum of Reasons Incumbents Do Not Run For Reelection

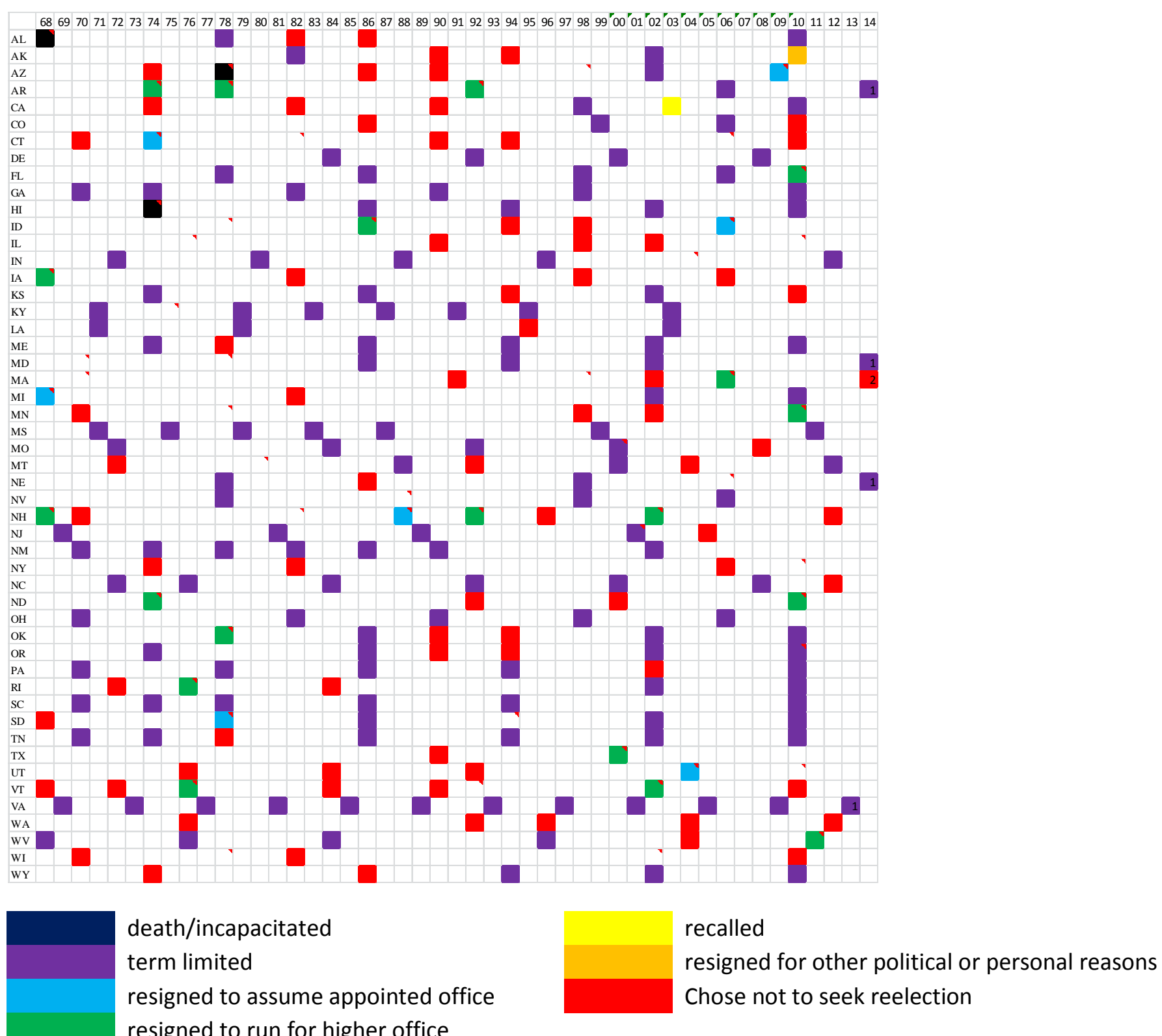


Figure 3: Sources of Gubernatorial Turnover: Term Limits, Deaths, and Appointments Only

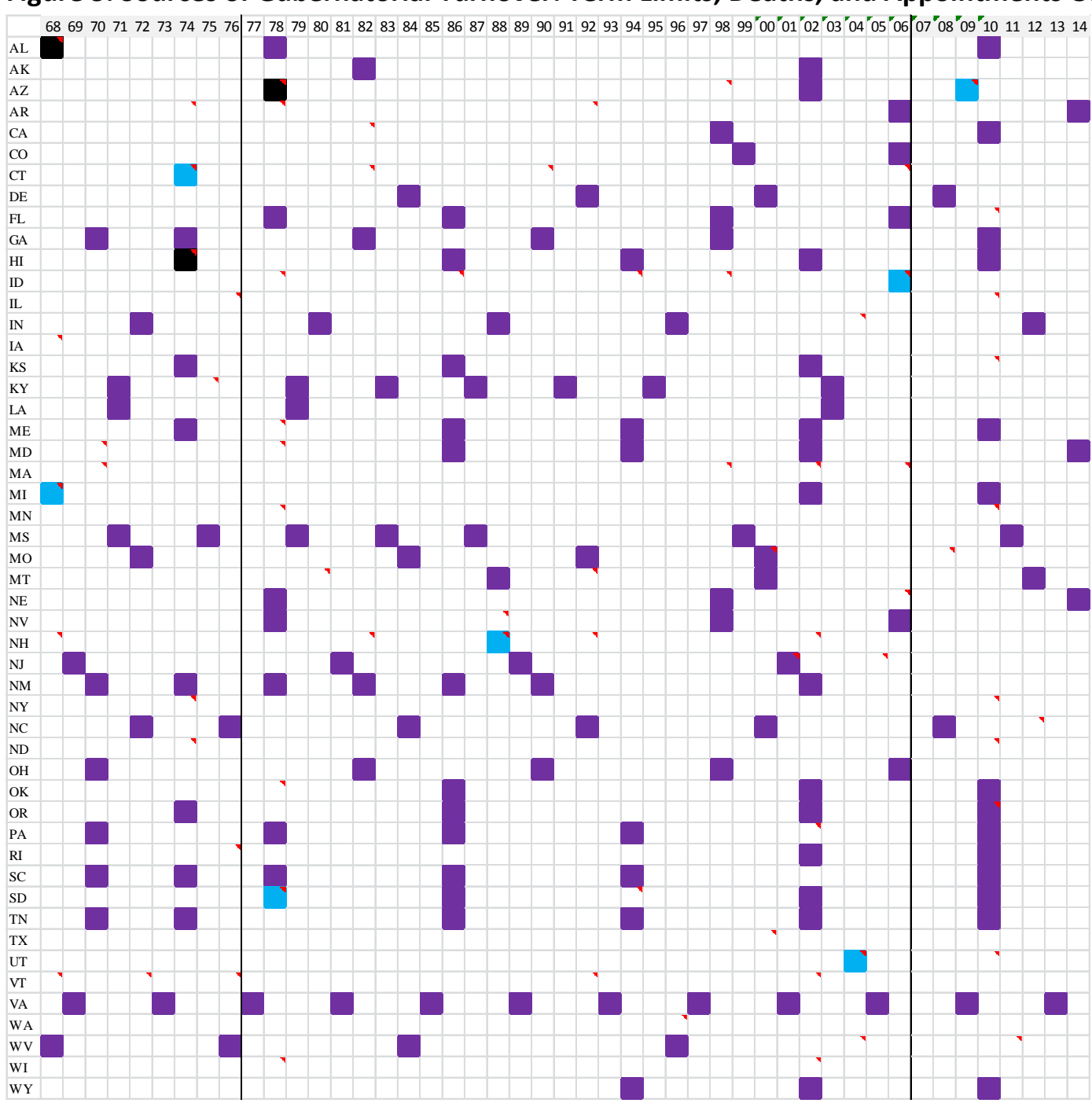

death/incapacitated

term limited

resigned to assume appointed office 